\title{
Thyroid Hormone-Responsive Genes in Developing Cerebellum Include a Novel Synaptotagmin and a hairless Homolog
}

\author{
Catherine C. Thompson \\ Department of Embryology, Carnegie Institution of Washington, Baltimore, Maryland 21210
}

\begin{abstract}
Proper development of the mammalian CNS requires sufficient thyroid hormone; thyroid hormone deficiency during a brief perinatal period produces severe neurological defects in humans and experimental animals. Thyroid hormone exerts its effects through nuclear receptors, which modulate the transcription of downstream genes in response to hormone binding. Surprisingly, few genes that are regulated by thyroid hormone receptors in the CNS have been described. Here, I report the isolation and characterization of genes that are expressed in response to thyroid hormone in developing rat brain. One such gene (Srg1) encodes a novel protein related to synaptotagmin, a protein involved in regulating neurotransmitter re-
\end{abstract}

lease; another ( $h r)$ encodes a putative zinc finger protein related to the product of a recently identified mouse gene, hairless. Both Srg1 and $h r$ are induced rapidly ( $<4 \mathrm{hr}$ ), suggesting that they are regulated directly by thyroid hormone. The temporal and spatial expression of both Srg1 and $h r$ is characteristic of genes important to nervous system development. Srg1 and $h r$ are likely part of a cascade of gene activation induced by thyroid hormone that is critical for CNS organization and development.

Key words: cerebellum; development; synaptotagmin; hairless; thyroid hormone; nuclear receptor
Thyroid hormone is essential for proper development of the mammalian CNS. In humans, inadequate levels of thyroid hormone during a critical perinatal period lead to a complex of deficits (termed cretinism), which include severe mental retardation and cerebellar ataxia (DeLong and Adams, 1991). Restoration of thyroid hormone to physiological levels within a brief postnatal period can restore normal development; after this time, the damage caused by thyroid hormone deficiency is irreversible (Eayrs, 1968; Morreale de Escobar et al., 1983; Schwartz, 1983). Studies in the rat have revealed multiple morphological, biochemical, and behavioral abnormalities associated with low levels of thyroid hormone. Morphological defects include reduction in dendritic branching, axonal density, and synapse number (Morreale de Escobar et al., 1983; Schwartz, 1983). Reduction in overall myelination is also observed and may be caused by delayed differentiation of oligodendrocytes (Barres et al., 1994).

The effects of thyroid hormone are mediated via the action of specific nuclear receptor proteins that function as ligand-activated transcription factors (Oppenheimer, 1991; Tsai and O'Malley, 1994; Mangelsdorf et al., 1995). The finding that thyroid hormone receptors are present in the developing brain suggests that, as in other tissues, thyroid hormone in the brain exerts its effects by regulating the expression of specific genes (TH-responsive genes), yet little is known about the genes regulated by these receptors.

Received July 26, 1996; revised Sept. 24, 1996; accepted Sept. 26, 1996.

This work was supported by the John Merck Fund at Community Trust, the American Cancer Society, and National Institutes of Health (National Institute of Diabetes and Digestive and Kidney Diseases). I thank L. Buckbinder, A. Lanahan, and Z. Wang for advice on subtractive hybridization; R. Simerly for advice on in situ hybridization; D. Brown and A. Kanamori for helpful discussions; O. Martin for technical assistance; A. Pinder for oligonucleotide synthesis; M. Sepanski for sectioning; H. Towle for the rat TR $\beta$ cDNA; and R. Evans for the rat growth hormone cDNA. I am grateful to S. Dymecki, C.-M. Fan, P. Rorth, and G. Seydoux for critical comments on this manuscript.

Correspondence should be addressed to Dr. Catherine C. Thompson, Department of Embryology, Carnegie Institution of Washington, 115 West University Parkway, Baltimore, MD 21210.

Copyright (C) 1996 Society for Neuroscience $0270-6474 / 96 / 167832-09 \$ 05.00 / 0$
Identification and functional characterization of target genes is critical, because such genes encode downstream effectors of receptor action. Of the many genes expressed in the developing nervous system, expression of only a few has been shown to be influenced by thyroid hormone (Farsetti et al., 1991; Munoz et al., 1991; Pipaon et al., 1992; Strait et al., 1992). Given the widespread effects of thyroid hormone deficiency on CNS development, it is likely that additional genes regulated by thyroid hormone remain to be discovered.

I have used subtractive hybridization coupled with PCR amplification to screen for TH-responsive genes expressed in rat brain within a critical developmental stage (postnatal days 10-15) and a specific region of the brain (cerebellum). Cerebellum was selected because it develops postnatally, at which time thyroid hormone is required, and striking effects of thyroid hormone deficiency on the cerebellum have been described (Nicholson and Altman, 1972a,b; Legrand, 1979). Several TH-responsive genes have been identified; two novel responsive genes with homology to classes of important regulatory proteins have been characterized. One gene (Srg1) encodes a novel protein related to synaptotagmin(s), a family of $\mathrm{Ca}^{2+} /$ phospholipid-binding proteins primarily found in the brain, at least one of which has a role in neurotransmitter release (Bennett and Scheller, 1994; Sudhof, 1995). Another gene identified in this screen encodes a putative zinc finger protein, likely the rat homolog of a recently identified mouse gene, hairless (Cachon-Gonzalez et al., 1994). The first step in characterizing these genes with respect to their potential role in neural development has entailed determination of kinetics and developmental and tissue-specific patterns of expression. Based on temporal and spatial patterns of expression, both $\operatorname{Srg} 1$ and $h r$ have properties of genes likely to be involved in nervous system development. The results of kinetic analysis suggest that $h r$ and $\operatorname{Srg} 1$ are among the first direct-response genes for thyroid hormone identified in the nervous system. 


\section{MATERIALS AND METHODS}

Animal care and treatment. Timed pregnant rats (Sprague Dawley) were obtained from Harlan Sprague Dawley (Indianapolis, IN). So that hyperthyroidism could be induced, pregnant rats were fed a low iodine diet (Purina Mills) and $0.025 \%$ methimazole (Sigma, St. Louis, MO) in their drinking water, starting at day 13 of gestation (E13) and continuing throughout the period of study. Methimazole blocks the synthesis of thyroid hormone in the mother and fetuses and, after birth, the pups (via nursing). For all experiments, the form of thyroid hormone used was L-T (3,5,3'-triiodothyronine; Sigma). The efficacy of methimazole treatment in reducing $\mathrm{T}_{3}$ levels was confirmed by direct measurement of serum $\mathrm{T}_{3}$ by RIA (Amersham, Arlington Heights, IL) and assessment of growth hormone $(\mathrm{GH})$ RNA levels in the anterior pituitary (see Fig. 1). Hypothyroid pups received daily subcutaneous injection of either saline (control) or $0.25 \mu \mathrm{g} / \mathrm{gm}$ body weight of $\mathrm{T}_{3}$. Treatment with hormone was for $48 \mathrm{hr}$. Injection of saline had no effect on serum $\mathrm{T}_{3}$ or $\mathrm{GH}$ levels. Injection of $T_{3}$ raised serum $T_{3}$ to slightly hyperthyroid levels (5-10 vs 1-2 nM) and restored $\mathrm{GH}$ expression to approximately euthyroid levels. For experiments with adult animals, animals were 10 weeks old; hypothyroid adults were treated with methimazole continuously from E13. Equal numbers of males and females were used for all experiments.

Construction of subtractive library. A cDNA library enriched for genes upregulated by thyroid hormone was constructed via subtractive hybridization/PCR amplification essentially as described (Wang and Brown, 1991). The starting material was $2 \mu \mathrm{g}$ of $\operatorname{poly}\left(\mathrm{A}^{+}\right)$RNA from the cerebella of 12-d-old hypothyroid animals injected with either saline (control) or $\mathrm{T}_{3}$ (TH-treated), as described above. cDNA synthesized from RNA isolated from TH-treated and control rats was digested with $A l u \mathrm{I}$, ligated to specific linkers (Wang and Brown, 1991), and amplified by PCR. Amplified material from the control cDNA was digested with EcoRI to cleave the PCR primer site and biotinylated with photoprobe biotin (Vector Laboratories, Burlingame, CA). Twenty-fold excess control cDNA was hybridized with TH-treated cDNA, followed by removal of biotinylated cDNA with streptavidin to eliminate control/TH-treated hybrids as well as unhybridized control cDNA. The remaining material was PCR-amplified, and the procedure was repeated two times. The final pool of cDNA was amplified, cloned into pBluescript (Stratagene, La Jolla, CA), and transformed into bacterial strain DH5 $\alpha$. DNA was prepared from individual colonies, digested with Eco RI to excise the cDNA insert, and separated by agarose gel electrophoresis. These gels were used for Southern analysis with the final pool of cDNA as probe. Approximately $30 \%$ of the colonies gave a detectable hybridization signal; these represented the most abundant members of the library and therefore those most enriched and likely to be TH-responsive. To confirm that isolates corresponded to TH-responsive genes, I used the cDNA inserts from positive clones as probes for Northern analysis of RNA prepared from control and $\mathrm{TH}$-treated hypothyroid P12 rats. Fragments from six different TH-responsive genes were isolated. The two genes chosen for further study on the basis of their kinetics and expression patterns (TRG16 and TRG37) are described; the other genes have not been characterized further.

$R N A$ preparation/Northern analysis. Animals were killed by decapitation, and tissues were removed and frozen in dry ice. RNA was prepared with acid/phenol as described (Chomczynski and Sacchi, 1987). Poly $\left(\mathrm{A}^{+}\right)$ RNA was selected by using oligo-dT-coupled magnetic beads (Promega, Madison, WI) or oligo-dT cellulose chromatography (Sambrook et al., 1989). For Northern analysis, RNA samples were separated on $1 \%$ agarose/formaldehyde gels and transferred to nitrocellulose. Radiolabeled probes were prepared by random priming (Feinberg and Vogelstein, 1984). Unless specified otherwise, the probe for $h r$ was a 2.2 HindIII fragment from nucleotide position 2245 to 3771 of the rat $h r$ cDNA; the probe for $\operatorname{Srg} 1$ was from nucleotide position 253 to 2071 of the cDNA. Ethidium bromide staining was used to assure that equivalent amounts of RNA were loaded per lane; filters were checked after blotting to confirm equivalent transfer of RNA. The probe for detecting TR $\alpha 1$ was an $H p h \mathrm{I}-X b a \mathrm{I}$ fragment from rbeA12 (Thompson et al., 1987) corresponding to the unique $\mathrm{C}$ terminus of TR $\alpha 1$ and included $250 \mathrm{bp}$ of $3^{\prime}$ untranslated region. The probe for detecting TR $\beta 1$ was a HindIII$X b a \mathrm{I}$ fragment from rc-erbA $\beta 1$ (Murray et al., 1988; kindly provided by $\mathrm{H}$. Towle, University of Minnesota) corresponding to the unique $\mathrm{N}$ terminus of TR $\beta 1$. The probe for rat growth hormone was an EcoRI fragment from the rGH cDNA (kindly provided by R. Evans, Salk Institute).

Isolation of full-length cDNA clones. An oligo-dT-primed cDNA library was constructed in lambda UNI-ZAP (Stratagene) under conditions recommended by the manufacturer. The starting material was RNA from the cerebella of hypothyroid P12 animals treated with thyroid hormone for $48 \mathrm{hr}$. The library was screened by using cDNA fragments isolated from the subtractive library as probes.

For TRG16 (Srg1), 10 different cDNAs were isolated; two contained the entire open reading frame. Six isolates differed by a deletion of 57 nucleotides between positions 196 and 253. Five isolates were $800 \mathrm{bp}$ longer at the $3^{\prime}$ end, likely attributable to internal priming of a stretch of consecutive $\mathrm{T}$ residues beginning at nucleotide 2063. For TRG37 (hr), four different cDNAs were isolated; the largest of these was $3.5 \mathrm{~kb}$. To isolate cDNA encompassing the rest of the rat $h r$ gene, I used a specific oligonucleotide corresponding to position $1898-1916$ in the cDNA (CT102) to reverse transcribe RNA from cerebellum, followed by $5^{\prime}$ RACE with a nested primer (CT103; Rapid Amplification of cDNA Ends, Life Technologies, Bethesda, MD) (Frohman et al., 1988; Loh et al., 1989). Specificity of the amplified cDNA was confirmed by hybridization with a nested oligonucleotide (CT104). This resulted in the isolation of an additional $1.4 \mathrm{~kb}$ cDNA. Specific oligonucleotides were synthesized to position $630-650$ in the cDNA (CT152) and used for reverse transcription, followed by $5^{\prime}$ RACE (CT153) to isolate an additional $500 \mathrm{bp}$. Specificity of the amplified cDNA was confirmed by hybridization with a nested oligonucleotide (CT154). Primers for 5' RACE (nucleotide positions correspond to the full-length cDNA) included the following: CT102, 5'-CAGATGTATCCTCAAGTCTG (nt 1898-1916); CT103, 5'-GATTCCCGGAGCCGAATCCT (nt 1877-1897); CT104, 5'-GGCCCTCTTTGCTCCTCTTGTTGCTGTGCC (nt 1837-1866); CT154, 5'-TAGGCACAGTGCCCCATGGT (nt 577-596); CT153, 5'-CCTCCAAAACCCAACAGGTTC (nt 600-621); and CT152, 5'-AGCCAGGAGTCTGGGGCGCTC (nt 630-650). Both 5' RACE products hybridized to the same size RNA as the original cDNA (data not shown). The combined size of the overlapping cDNAs was $5.3 \mathrm{~kb}$ and contained the entire open reading frame.

The complete nucleotide sequences for $\operatorname{Srg} 1$ and $h r$ were determined on both strands by the chain termination method (Sequenase/USB, Cleveland, $\mathrm{OH}$ ) with either subcloned restriction fragments or specific oligonucleotides. The complete nucleotide and amino acid sequences have been submitted to GenBank under accession numbers U71293 (hr) and U71294 ( $\operatorname{Srg} 1)$.

Cell culture. GH1 (rat pituitary) cells were obtained from ATCC (Rockville, MD). Cells were grown in DMEM supplemented with $10 \%$ fetal calf serum. For induction experiments, serum was depleted of thyroid and steroid hormones by treatment with AG-1-X8 resin (BioRad, Hercules, CA) and charcoal (Sigma), as described (Samuels et al., 1979). Cells were grown for $2 \mathrm{~d}$ in hormone-depleted media; then thyroid hormone $\left(\mathrm{T}_{3}\right)$ was added to $10^{-7} \mathrm{M}$, and cycloheximide was added to 10 $\mu \mathrm{g} / \mathrm{ml}$. After treatment for $16 \mathrm{hr}$, cells were harvested, and RNA was prepared as described.

In situ hybridization. Animals (P14) were killed by decapitation, brains were removed, and cerebellum and brain stem were separated from midbrain and forebrain and frozen with dry ice/ethanol in O.C.T. compound embedding medium (Baxter, McGaw Park, IL). Sections $(10 \mu \mathrm{m})$ were prepared with a cryostat and transferred to slides (ProbeOn Plus, Fisher Scientific, Pittsburgh, PA). Sections were stored at $-20^{\circ} \mathrm{C} .{ }^{35} \mathrm{~S}-$ labeled cRNA probes were prepared by synthesis with either T3 or T7 RNA polymerase in the presence of ${ }^{35} \mathrm{~S}$-UTP (New England Nuclear, Boston, MA). Hybridization conditions were as described (Simmons et al., 1989; Simerly and Young, 1991), except that fixation was for $1 \mathrm{hr}$ and proteinase $\mathrm{K}$ treatment was for $15 \mathrm{~min}$. Hybridization with sense strand cRNA was used as a negative control. Autoradiographic images were obtained by direct exposure of hybridized sections to x-ray film (Amersham Hyperfilm $\beta$-max). Probe for $h r$ was from nucleotide 2703 to 5186 of the cDNA; probe for Srg1 spanned nucleotides 783-1574 of the cDNA.

\section{RESULTS}

\section{Isolation of TH-responsive genes from developing rat brain}

To identify genes regulated by thyroid hormone in developing brain, I treated pregnant rats with methimazole to induce hypothyroidism in their pups (see Materials and Methods). Because the critical period for thyroid hormone action in rat brain is between postnatal days 10 and 15 , on postnatal day 12 (P12) one-half of the methimazole-treated pups were injected with thyroid hormone (TH-treated), the other one-half with saline 

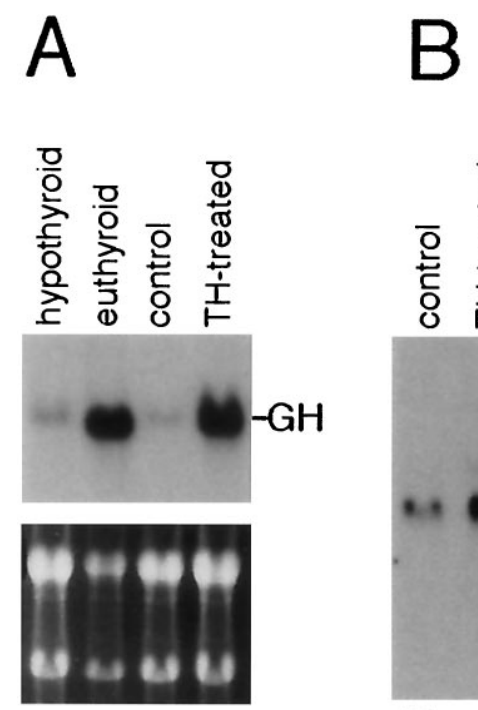

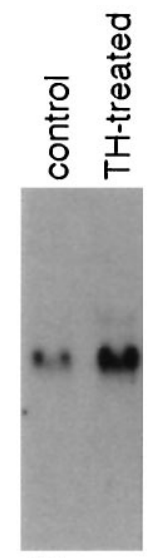

TRG16

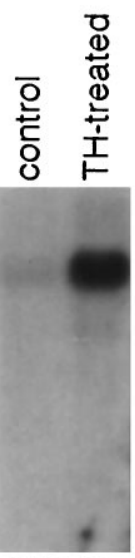

TRG37

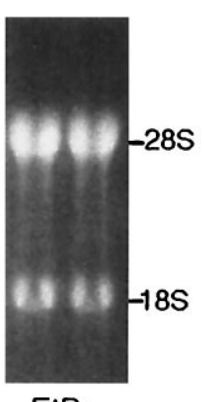

$\mathrm{EtBr}$
Figure 1. Isolation of novel thyroid hormone-responsive genes from developing rat brain. $A$, Influence of thyroid hormone on expression of rat growth hormone $(G H)$ mRNA in methimazole-treated rats. RNA prepared from the pituitaries of 12-d-old rats was used for Northern analysis with a radiolabeled rGH cDNA probe. hypothyroid, Methimazole-treated; euthyroid, untreated; control, hypothyroid animals injected with saline; TH-treated, hypothyroid animals injected with thyroid hormone. Thyroid hormone treatment was for $24 \mathrm{hr}$. Top panel, Autoradiograph of Northern blot; bottom panel, ethidium bromide-stained gel. $B$, Northern analysis for two novel thyroid hormone-responsive genes (TRG16 and TRG37). A cDNA fragment isolated from the subtracted library is the probe; total RNA (15 $\mu \mathrm{g}$ per lane) prepared from cerebellum of hypothyroid P12 rats injected with saline or thyroid hormone for $48 \mathrm{hr}$ was used. Right panel, Ethidium bromide-stained gel indicates equivalent loading and positions of $18 \mathrm{~S}$ and $28 \mathrm{~S}$ RNAs.

(control). Treatment with thyroid hormone was for $48 \mathrm{hr}$. To demonstrate the efficacy of this paradigm, I monitored the level of mRNA for a known responsive gene (growth hormone). Growth hormone mRNA was greatly reduced in the pituitaries of hypothyroid animals and was restored to euthyroid (normal) levels after thyroid hormone treatment (Fig. 1A). RNA isolated from the cerebella of control and TH-treated animals was the starting material for construction of a cDNA library enriched for genes upregulated by thyroid hormone. The procedure for preparing the library is based on subtractive hybridization coupled with PCR amplification (Wang and Brown, 1991; see Materials and Methods). Identification of positive clones (cDNA fragments originating from TH-responsive genes) was accomplished by using the isolated fragments as probes for Northern analysis. Fragments that detected higher expression in RNA from cerebella of THtreated animals relative to control animals were judged to be from TH-responsive genes. Fragments corresponding to six different TH-responsive genes were isolated. Two genes were chosen for further study on the basis of their kinetics and expression patterns (described below); Northern analysis for these genes (TRG16 and TRG37) is shown in Figure $1 B$. Low basal level expression is observed for both TRG16 and TRG37 in hypothyroid cerebellum. Expression of TRG16 is induced approximately threefold by thyroid hormone; induction of TRG37 is $\sim 10$-fold.

\section{Identification of novel TH-responsive genes}

To obtain full-length cDNAs for TRG16 and TRG37, I constructed a cDNA library, which was then screened using the isolated cDNA fragments as probes. For TRG37, I used library screening and 5' RACE to isolate a combined cDNA of $5.3 \mathrm{~kb}$. The open reading frame (ORF) contained within this sequence encodes a predicted protein of 1207 amino acids. The only recognizable structural motif in the primary amino acid sequence is a single putative zinc finger (Fig. $2 A$ ). A search of the database (GenBank) revealed that this putative protein is similar to that encoded by a recently identified mouse gene, hairless $(\mathrm{hr})$. The TRG37 ORF is $94 \%$ identical to the ORF of the mouse hairless gene, suggesting that TRG37 is the rat homolog of hairless. Therefore, TRG37 was renamed $h r$.

For TRG16, I isolated multiple cDNAs that contained an ORF encoding a predicted protein of 421 amino acids (Fig. 2B). A search of the database (GenBank) revealed that this putative protein is most similar to synaptotagmin(s). Synaptotagmins share a common structure that includes a $\mathrm{C}$-terminal region consisting of two domains related to the regulatory domain of protein kinase $\mathrm{C}$ (C2 domains; Fig. 2C). The eight members of the synaptotagmin family are related within this region (41-89\% amino acid identity with synaptotagmin I), but they do not show significant amino acid identity outside this region. TRG16 has between 26 and $37 \%$ amino acid identity with the different synaptotagmins in this C-terminal region. Also characteristic of synaptotagmins, the $T R G 16$ ORF lacks a signal sequence but has a hydrophobic region near the $\mathrm{N}$ terminus, a putative transmembrane domain. Because of this homology with synaptotagmins, TRG16 has been termed Srg1 (Synaptotagmin related gene 1).

\section{Srg 1 and $h r$ respond rapidly to thyroid hormone}

Genes that respond to hormones or other activators often are divided into the broad categories of primary (direct) response genes and secondary (indirect) response genes. Primary or direct response genes are defined as those that respond rapidly and without the need for protein synthesis, indicating that they are direct targets of regulation by a particular transcriptional activator. The induction of most previously described TH-responsive genes is blocked by protein synthesis inhibitors, suggesting that they are secondary response genes (Kanamori and Brown, 1992).

To determine whether $S r g 1$ and $h r$ are induced directly by thyroid hormone, I examined the kinetics of regulation. Hypothyroid neonatal (P12) rats were injected with thyroid hormone and sacrificed at various times after treatment. Northern analysis of RNA prepared from cerebellum shows that both $\operatorname{Srg} 1$ and $h r$ are rapidly upregulated (Fig. 3). Induction of $S r g 1$ occurs within $2 \mathrm{hr}$ of treatment, reaching maximal levels by $4-8 \mathrm{hr}$. $h r$ is induced within $4 \mathrm{hr}$, reaching maximal levels by $8-12 \mathrm{hr}$. The rapid response of $\operatorname{Srg} 1$ and $h r$ suggests that these genes may be direct targets of thyroid hormone action.

Cultured cells were used to determine whether induction of $h r$ by thyroid hormone (TH) could be blocked by inhibition of protein synthesis with cycloheximide (CHX); Srg1 was not analyzed, because it was not detected in any of the cell lines tested. GH1 (rat pituitary) cells grown in the absence of $\mathrm{TH}$ were treated with $\mathrm{TH}, \mathrm{CHX}$, or both for $16 \mathrm{hr}$. Northern analysis shows that $\mathrm{TH}$ induces a fourfold increase in $h r$ expression and that this increase is resistant to cycloheximide treatment (Fig. 3). Simultaneous treatment with $\mathrm{CHX}$ and $\mathrm{TH}$ showed increased expression relative to $\mathrm{CHX}$ or $\mathrm{TH}$ alone, likely attributable to stabilization of the message by $\mathrm{CHX}$. Hybridization of the same blot with a probe for growth hormone $(\mathrm{GH})$ showed that, as expected, induction of $\mathrm{GH}$ by $\mathrm{TH}$ was partially blocked by cycloheximide (data not shown). The 

A
1
MGLRSSCFVLTLQDPPLGEPHEGRRVMESMPSFLKDTPAWEKTAPVNGIV
51 GQEPGTSPQDGLHHGALCLGEPVPFWRGVLSAPDSWLPPGFLQGPKDTLS
101 VVEGEGSRNGERKANWLGSKEGLRWKEAMLAHPLAFCGPACPPRYGPIIP
151 EHSSGHPKSDPVAFRPLHCPFLLETKILERAPFWVPTCLPPYLMSSLPPE
201 RSYDWPLAPSPWVYSGSQPKVPSAFSLGSKGFYHKDPNILRPAKEPLAAS
251 ESGMLGLAPGGHLQQACDAEGPSLHQRDGETGAGRQQNLCPVFLGYPDTV
301 PRTPWPSCPPGLVHTLGNVWAGPGSNSFGYQLGPPVTPRCPSPGPPTPPG
351 GCCSSHLPAREGDPGPCRKCQDSPEGSSSGPGESSEERNKAGSRASPPSH
401 HTKLKKTWLTRHSEQFECPGGCPGKGESPATGLRALKRAGSPEVQGARGP
451 APKRPSHTFPGTGRQGARAWQETPETSTGSKAEAQQQEEQRGPRDGRIRL
501 RESRLEDTSCQHHLAGVTQCPSCVQAAGEVEILTSHSQKSHKLPLEEKPL
551 EEDSCATSEEGGGSSPEASINKGLAKHLLSGLGDRLCRLLRKEREALAWA
601 QREGQGPAMTEDSPGIPHCCSSRCHHGLFNTHWRCSHCSSHRLCVACGRIAG
651 AGKNREKTGSREQRTDDCAQEAGHAACSLILTQFVSSQALAELSTVMHQV
701 WAKFDIRGHCFCQVDARVWAPGDGGQQKEPTEKTPPAPQLSCNGDSNRTK
751 DIKEETPDSTESPAEDRAGRSPLPCPSLCELLASTAVKLCLGHERIHMAF
801 APVTPALPSDDRITNILDSI IAQVVERKIQEKALGPGLRAGSGLRKGLSL
851 PLSPVRTQLSPPGALLWLQEPRPKHGFRLFQEHWRQGQPVLVSGIQKTLR
901 LSLWGMEALGTLGGQVQTLTALGPPQPTSLDSTAFWKGFSHPEARPKLDE
951 GSVLLLHRPLGDKDESRVENLASSLPLPEYCAHQGKLNLASYLPLGLTLH
1001 PLEPQLWAAYGVNSHRGHLGTKNLCVEVSDLISILVHAEAQLPPWYRAQK
1051 DFLSGLDGEGLWSPGSQTSTVWHVFRAQDAQRIRRFLQMVCPAGAGTLEP
1101 GAPGSCYLDSGLRRRLREEWGVSCWTLLQAPGEAVLVPAGAPHQVQGLVS
1151 TISVTQHFLSPETSALSAQLCHQGASLPPDHRMLYAQMDRAVFQAVKVAV
1201 GTLQEAK 1207

induction of $h r$ expression by thyroid hormone in the absence of protein synthesis shows that $h r$ responds directly to thyroid hormone.

\section{Expression patterns of Srg1 and $h r$ are consistent with} regulation by thyroid hormone during development

To establish whether $\operatorname{Srg} 1$ and $h r$ are regulated by thyroid hormone during normal development, I determined the expression pattern of both genes and compared it with that of thyroid hormone receptors (TR $\alpha 1$ and $\mathrm{TR} \beta 1)$. TH-responsive genes likely to function in neural development should be expressed at the time known to be important for the effect of thyroid hormone (postnatal days 10-15) and when thyroid hormone receptors are present. Northern analysis of RNA isolated from embryonic and postnatal brain shows that $\operatorname{Srg} 1$ and $h r$ both are expressed at high levels shortly after birth, reaching a peak between postnatal days 14 and 21 (Fig. 4). Consistent with previous observations (Strait et al., 1990; Forrest et al., 1991; Mellström et al., 1991; Bradley et al., 1992), expression of TR $\beta 1$ rises at birth, immediately preceding expression of $\operatorname{Srg} 1$ and $h r$. TR $\alpha 1$ is expressed prenatally and remains at high levels after birth (Forrest et al., 1991; Mellström et al., 1991; Bradley
B

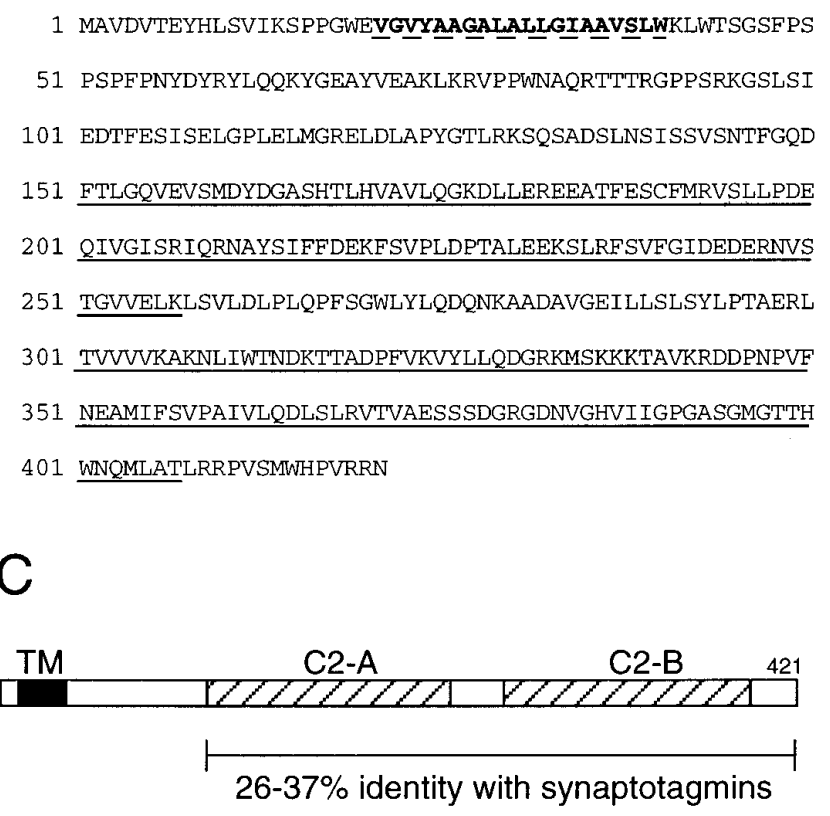

Figure 2. TRG37 encodes a putative zinc finger protein related to hairless; TRG16 encodes a novel synaptotagmin. A, Amino acid sequence of TRG37 (94\% amino acid identity with ORF from mouse hairless gene). Cysteine residues potentially involved in formation of a zinc finger are underlined. $B$, Amino acid sequence of TRG16 (Srg1). Protein kinase C-related (C2) domains are underlined; putative transmembrane domain is indicated by dashed underline. C, Schematic representation of Srg1 structure. Cross-hatched boxes represent C 2 domains; Srg1 shows between 26 and $37 \%$ amino acid identity in the region encompassing the $\mathrm{C} 2$ domains with synaptotagmins I-VIII $(19-31 \%$ in $C 2-A ; 33-42 \%$ in $C 2-B)$. Black box $(T M)$ at the $\mathrm{N}$ terminus indicates putative transmembrane domain. The complete nucleotide sequences have been submitted to GenBank under accession numbers U71293 (hr) and U71294 (Srg1).

et al., 1992). Therefore, both $\operatorname{Srg} 1$ and $h r$ are expressed at the appropriate time in normal development, both with respect to the critical time frame for the effect of thyroid hormone and the presence of thyroid hormone receptors.

\section{Srg1 and $h r$ show tissue-restricted expression}

To determine whether expression of $S r g 1$ and $h r$ is restricted to the CNS, I performed Northern analysis of RNA isolated from various rat tissues. Expression of Srg1 was not detected outside the nervous system in either neonatal (Fig. $5 A$ ) or adult animals (data not shown). Neonatal expression of $h r$ is abundant in brain and skin and is also detected at low levels in other tissues, including gut, lung, muscle, and pituitary (Fig. $5 A$ ). The expression pattern is the same in adult tissues, except for an additional RNA of $\sim 3.5 \mathrm{~kb}$ detected in brain (see Fig. 4). In contrast to brain, the hairless gene is not regulated by thyroid hormone in skin (Fig. 5B).

\section{Srg1 and $h r$ are expressed specifically in the internal granule cell layer of the cerebellum}

To examine more precisely the expression of $\operatorname{Srg} 1$ and $h r$ in the cerebellum, I used in situ hybridization. Hybridization of coronal 

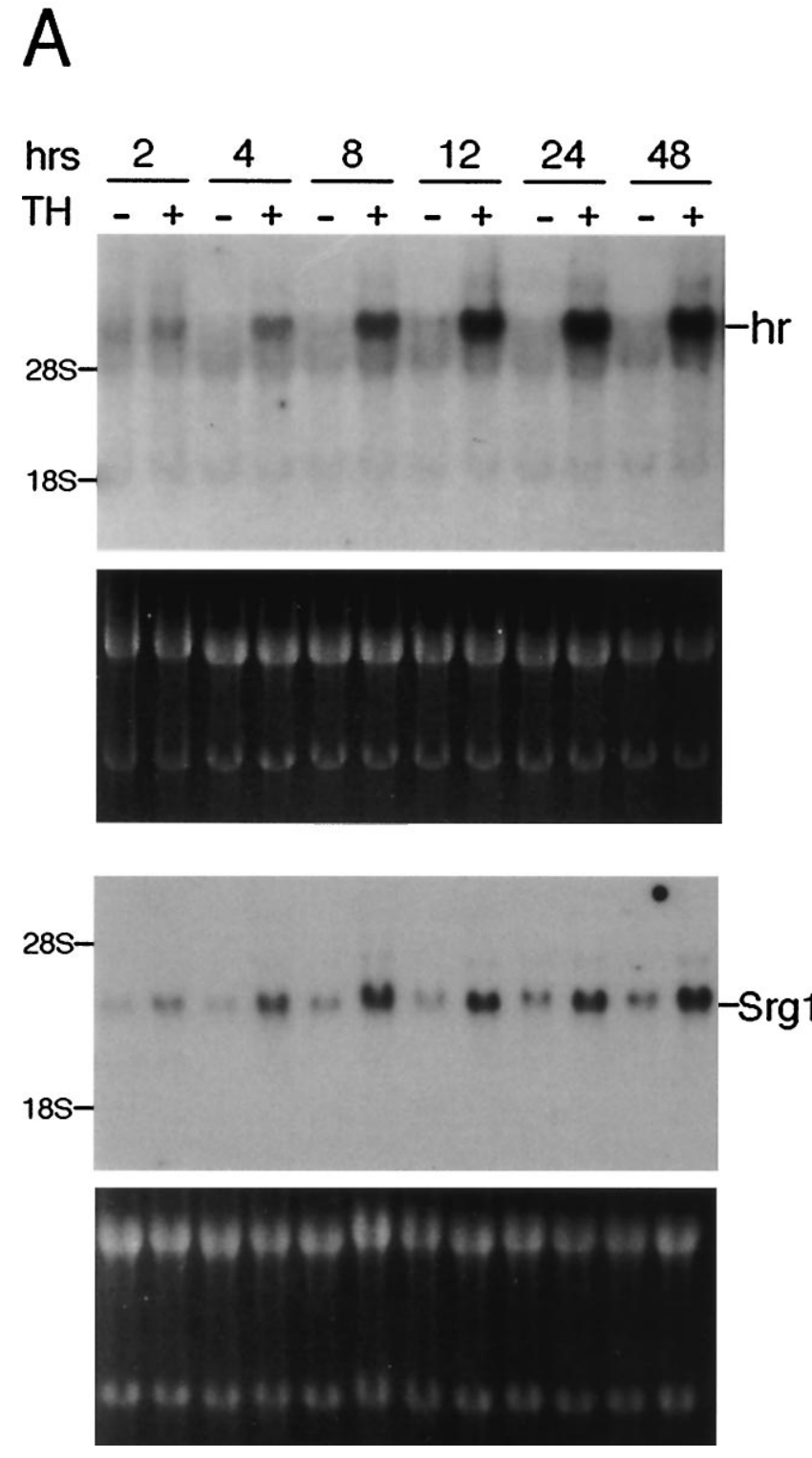

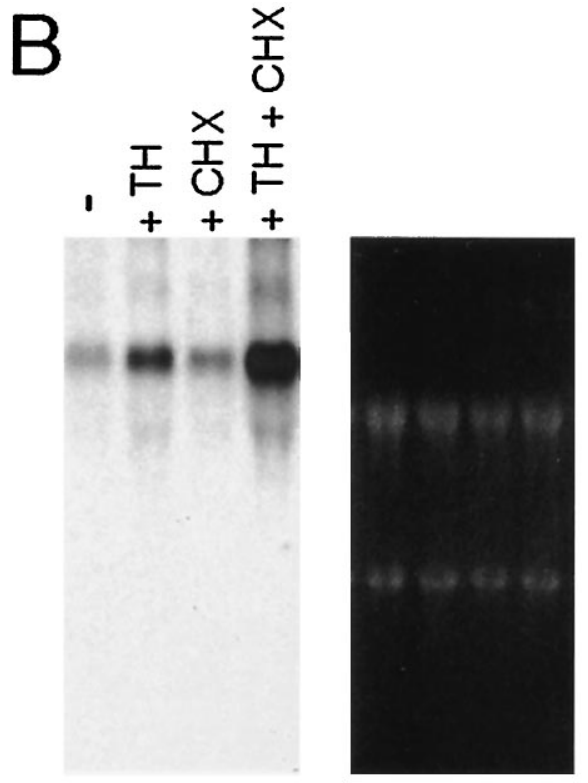

Figure 3. Srg1 and $h r$ respond rapidly to thyroid hormone. So that the kinetics of response to thyroid hormone could be determined, 12-d-old hypothyroid rats were injected with saline $(-)$ or thyroid hormone $(+)$ and killed at various times after injection. Total RNA (10 $\mu \mathrm{g}$ per lane) prepared from cerebellum was used for Northern analysis with ${ }^{32} \mathrm{P}$-labeled cDNA probes for $h r$ (top) or Srgl (bottom). $(-)$, Control; $(+)$, TH-treated; $h r, h r$ after injection. Two independent experiments gave the same results. $B, h r$ responds to thyroid hormone in the absence of protein synthesis. GH1 (rat pituitary) cells were grown in hormonefree media (-) for $2 \mathrm{~d}$. $\mathrm{T}_{3}$ was added to $10^{-7} \mathrm{M}(T H)$; cycloheximide $(\mathrm{CHX})$ was added to $10 \mu \mathrm{g} / \mathrm{ml}$ for $16 \mathrm{hr}$. Total RNA (15 $\mu \mathrm{g}$ per lane) was used for Northern analysis. sections from P14 rats showed that both $\operatorname{Srg} 1$ and $h r$ were expressed in the internal granule cell layer (IGL) of the cerebellum (Fig. 6). During maturation of the cerebellum, cells migrate from the external granule cell layer (EGL) to the IGL, a region where the cell bodies of maturing neurons are found (Altman, 1972a-c; Rakic, 1972). The absence of expression in the EGL and presence in the IGL suggest that $\operatorname{Srg} 1$ and $h r$ are expressed only in differentiated cells. To determine whether injection of hypothyroid animals with thyroid hormone restored this expression pattern, I used in situ hybridization of sections from hypothyroid animals injected with either saline or thyroid hormone (Fig. 6D). For both Srgl and $h r$, expression induced in the cerebellum of thyroid hormone-treated animals was indistinguishable from expression in euthyroid animals. Little or no expression above background was detected in hypothyroid animals. Induction of $\operatorname{Srg} 1$ by thyroid hormone was greater in cerebellum than in more rostral brain regions (data not shown).

Although this strategy initially focused on the cerebellum, thyroid hormone affects many different regions of the brain, suggesting that at least some TH-responsive genes are expressed outside the cerebellum. In situ hybridization was used to examine expression of $\operatorname{Srg} 1$ and $h r$ in other regions of the brain. $h r$ is broadly expressed at low levels throughout the forebrain and midbrain (data not shown), whereas Srg1 shows a more restricted expression pattern (Fig. 7). High levels of Srgl expression are detected in several regions of the brain, including the cortex, caudate putamen, hippocampus, thalamus, piriform cortex, and amygdala. Previous studies have shown that these regions express other synaptotagmins as well (Ullrich et al., 1994). This is a common feature of synaptotagmins; different family members are often coexpressed. Because Srgl is regulated by thyroid hormone, this raises the question of whether synaptotagmins are regulated by thyroid hormone as well. Northern analysis of RNA from the brains of hypothyroid and normal animals showed that two other synaptotagmins (syt I and syt III) are not regulated by thyroid hormone (data not 

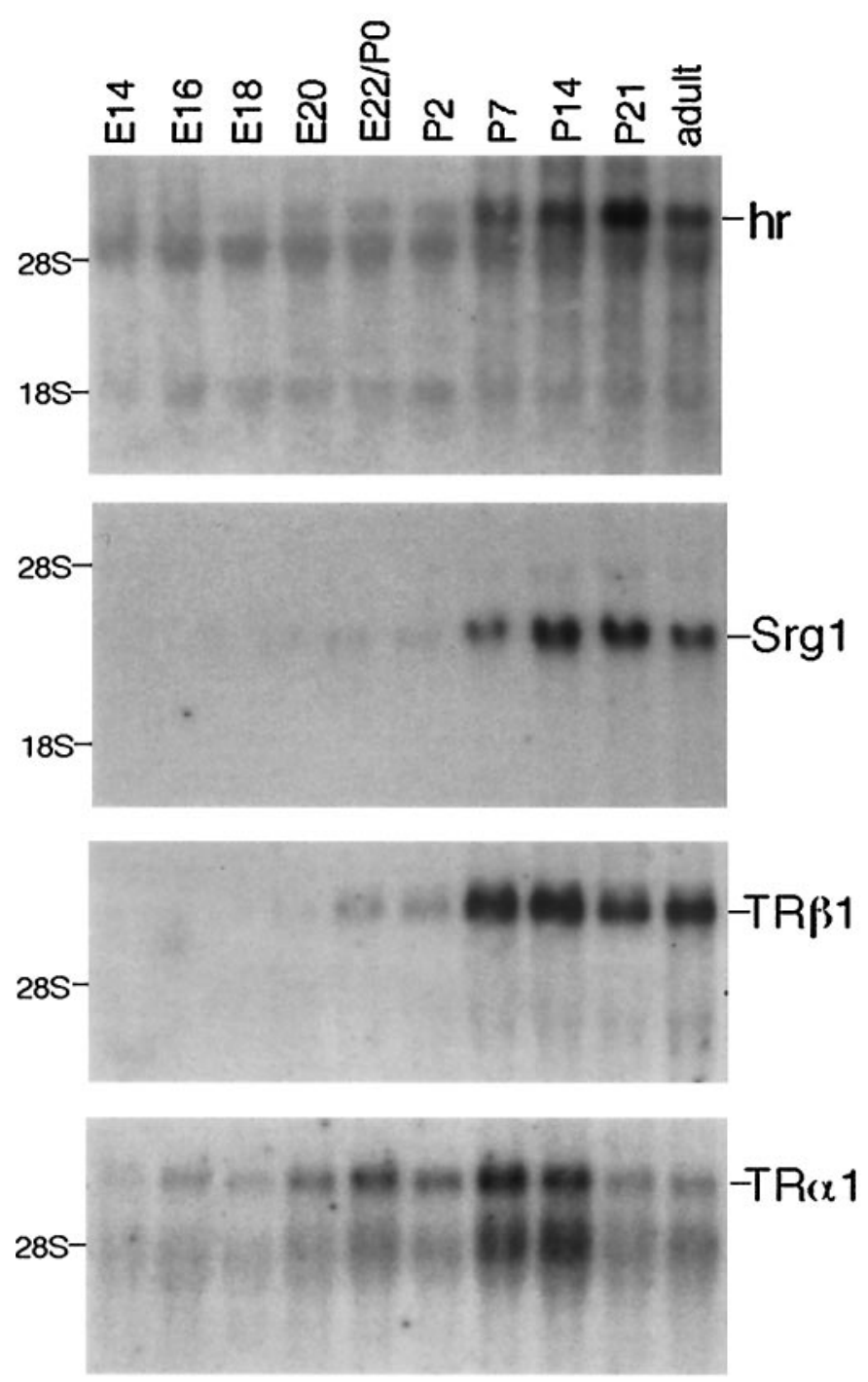

Figure 4. Developmental expression of $h r$ and Srg1 in brain. Northern analysis of RNA prepared from the brains of embryonic and neonatal rats. Parallel blots (10 $\mu \mathrm{g}$ of total RNA per lane) were hybridized with ${ }^{32} \mathrm{P}$ labeled cDNA probes from $h r, S r g 1, T R \beta 1, T R \alpha 1$ (top to bottom). E, Day of gestation; $E 22 / P 0$, birth; $P$, days after birth.

shown). Thus, regulation by thyroid hormone is not a feature common to all members of the synaptotagmin family and may be a property unique to $\operatorname{Srg} 1$.

\section{DISCUSSION}

\section{Novel TH-responsive genes isolated from neonatal rat brain}

This study describes the identification and initial characterization of genes regulated by thyroid hormone in developing rat brain. Srgl and $h r$ represent the most rapidly regulated ( $<4 \mathrm{hr}$ ) THresponsive genes identified in the mammalian nervous system; to date, $h r$ is also the most highly induced ( $>10$-fold). $h r$ does not require protein synthesis for upregulation and thus is a direct target of thyroid hormone receptors. $\operatorname{Srg} 1$ is activated with similar kinetics, so it is likely that $\mathrm{Srg} 1$ is a direct response gene as well. Direct response genes are of particular interest because such genes likely constitute the first step in the genetic program responsible for TH-mediated aspects of neural development.

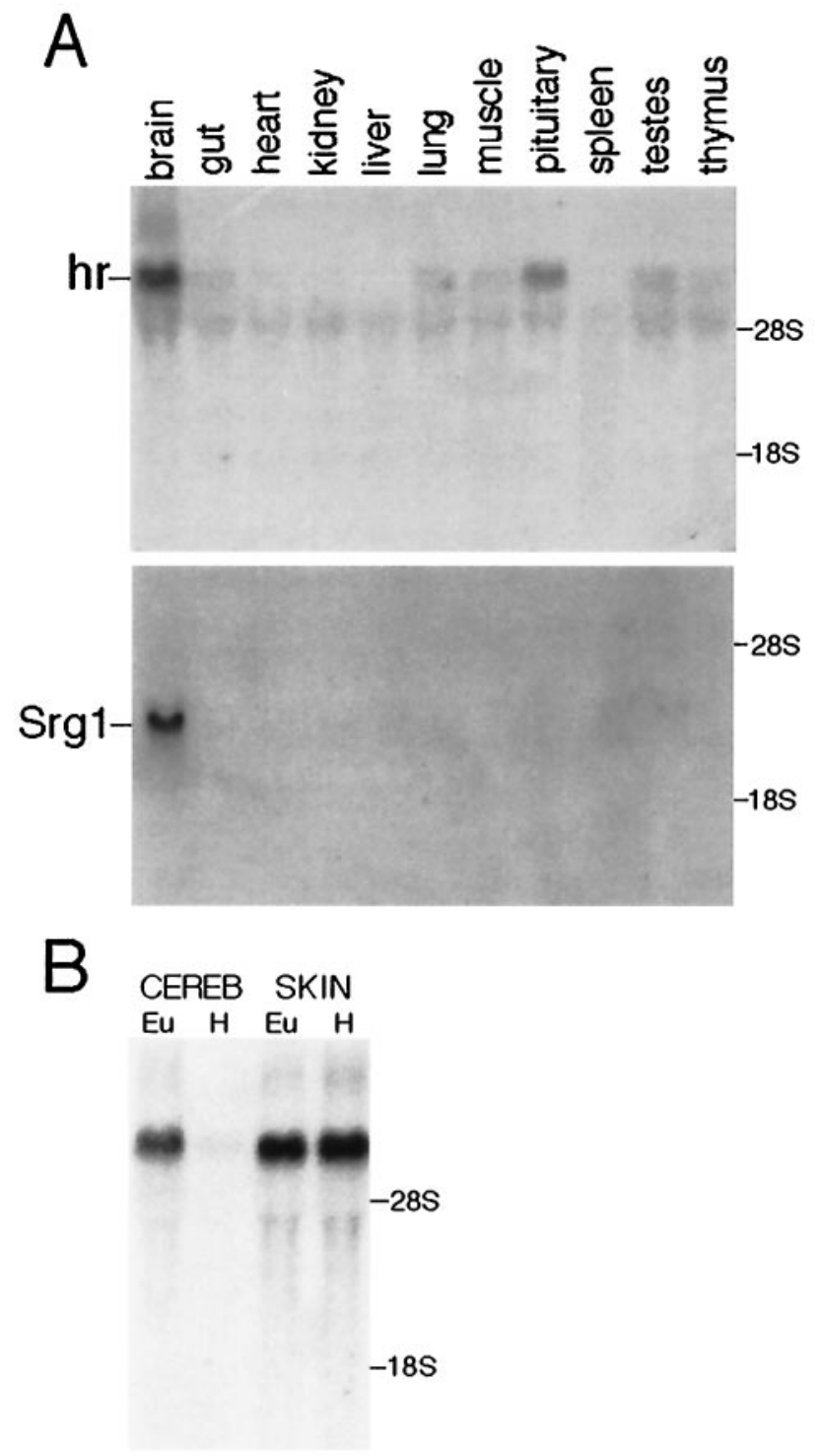

Figure 5. Tissue distribution of $h r$ and $\operatorname{Srg} 1 . A$, RNA was prepared from various tissues collected from euthyroid animals on postnatal day 12 . Total RNA (15 $\mu \mathrm{g}$ per lane) was used for Northern analysis with ${ }^{32} \mathrm{P}$-labeled cDNA probes from $h r$ (top) or Srgl (bottom). Spleen RNA is somewhat degraded; all other RNAs are equivalent, as assessed by ethidium bromide staining. $B, h r$ is regulated by thyroid hormone in brain, but not in skin. Shown is Northern analysis of RNA from cerebellum (CEREB) and skin $(S K I N)$ of hypothyroid and euthyroid neonatal (P14) rats. Eu, Euthyroid; $H$, hypothyroid.

Srgl and $h r$ have been shown to be regulated by thyroid hormone in this experimental system; it is likely that they are regulated by thyroid hormone during normal development as well. Both genes are highly expressed within the first 2 weeks after birth, a time known to be crucial for the effect of thyroid hormone on development. Temporal expression of Srgl and $h r$ also is correlated with the presence of thyroid hormone receptors. As shown here and consistent with previous studies examining receptor mRNA levels in the brain (Strait et al., 1990; Forrest et al., 1991; Mellstrom et al., 1991; Bradley et al., 1992), expression of Srg1 and $h r$ immediately follows that of TR $\beta 1$. TR $\alpha 1$ is present at this time as well, but unlike TR $\beta 1$ it is also present at high levels prenatally. The timing of $S r g 1$ and $h r$ expression suggests that 

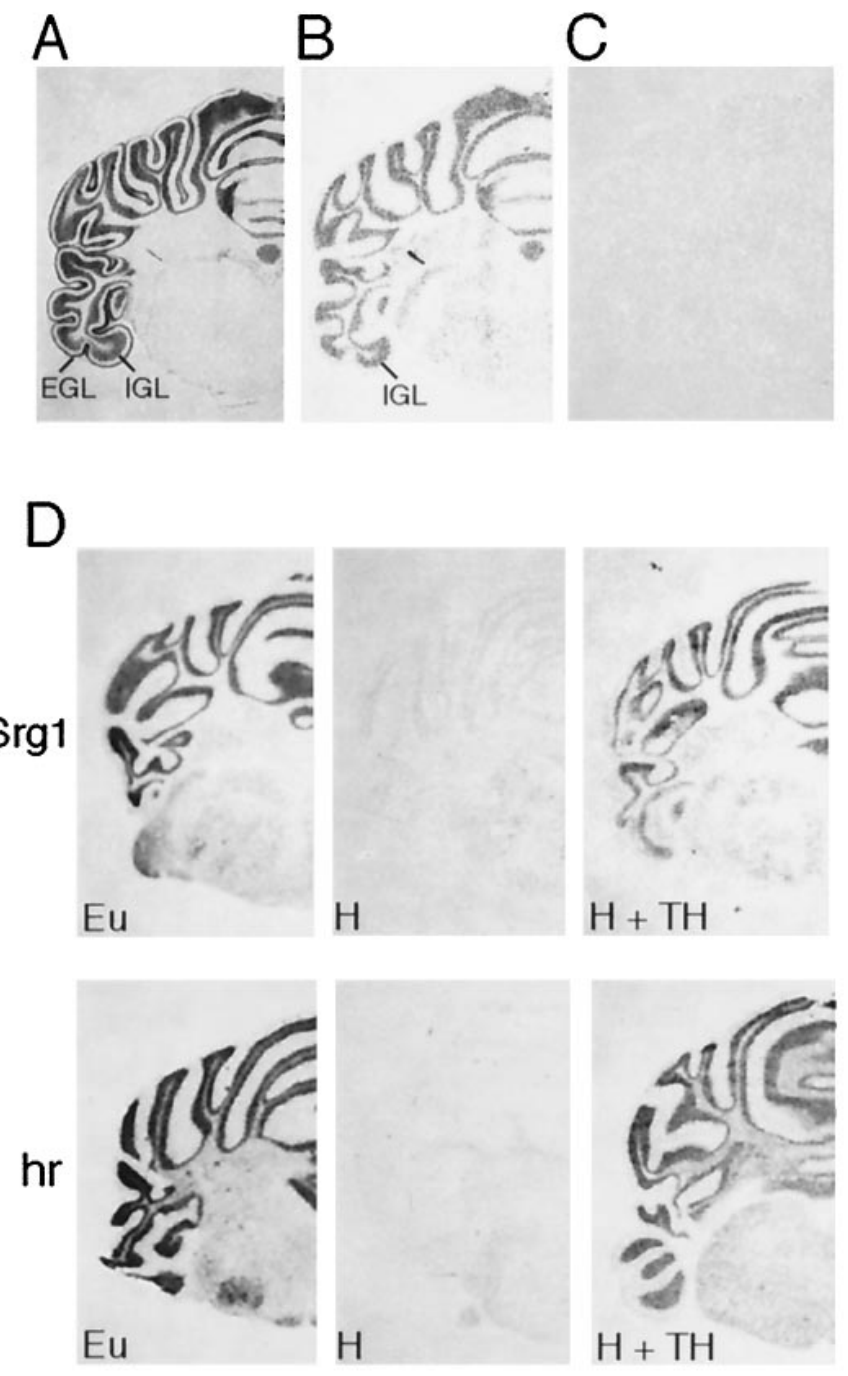

Figure 6. Expression of $\operatorname{Srg} 1$ and $h r$ in neonatal cerebellum. Shown is in situ hybridization of coronal sections from cerebellum of P14 rat. Shown are results from $S r g 1$; signal in the cerebellum with an $h r$ probe is comparable (see $B) . A$, Thionine counterstain (after hybridization); $B$, hybridization with antisense probe; $C$, hybridization with sense probe. $E G L$, External granule cell layer; $I G L$, internal granule cell layer. Sections (10 $\mu \mathrm{m})$ of frozen tissue were hybridized with ${ }^{35} \mathrm{~S}$-labeled cRNA probes. $B, C$, Shown are photomicrographs of an autoradiographic image of the hybridized section exposed directly to x-ray film. $D$, Expression induced by thyroid hormone injection is indistinguishable from euthyroid expression in neonatal cerebellum. In situ hybridization of coronal sections from cerebella of P14 rats using a cRNA probe from Srg1 (top) or $\mathrm{hr}$ (bottom). Eu, Euthyroid; H, hypothyroid; $H+T H$, hypothyroid treated with thyroid hormone for $48 \mathrm{hr}$. Sections were hybridized simultaneously with the same probe preparation. Shown are photomicrographs of the autoradiographic image of the hybridized section exposed directly to $\mathrm{x}$-ray film.

regulation of these genes is attributable either to the increased levels of thyroid hormone present after birth or specific regulation by $\operatorname{TR} \beta 1$. These alternatives can be distinguished by examining expression of these genes after thyroid hormone levels are raised precociously.

In situ hybridization analysis of Srgl and $h r$ showed that both are expressed in the IGL, but not the EGL, of the cerebellum. In the course of cerebellar development, neuroblasts residing in the EGL undergo terminal mitosis. The resulting postmitotic cells migrate inward and ultimately populate the IGL (Altman,
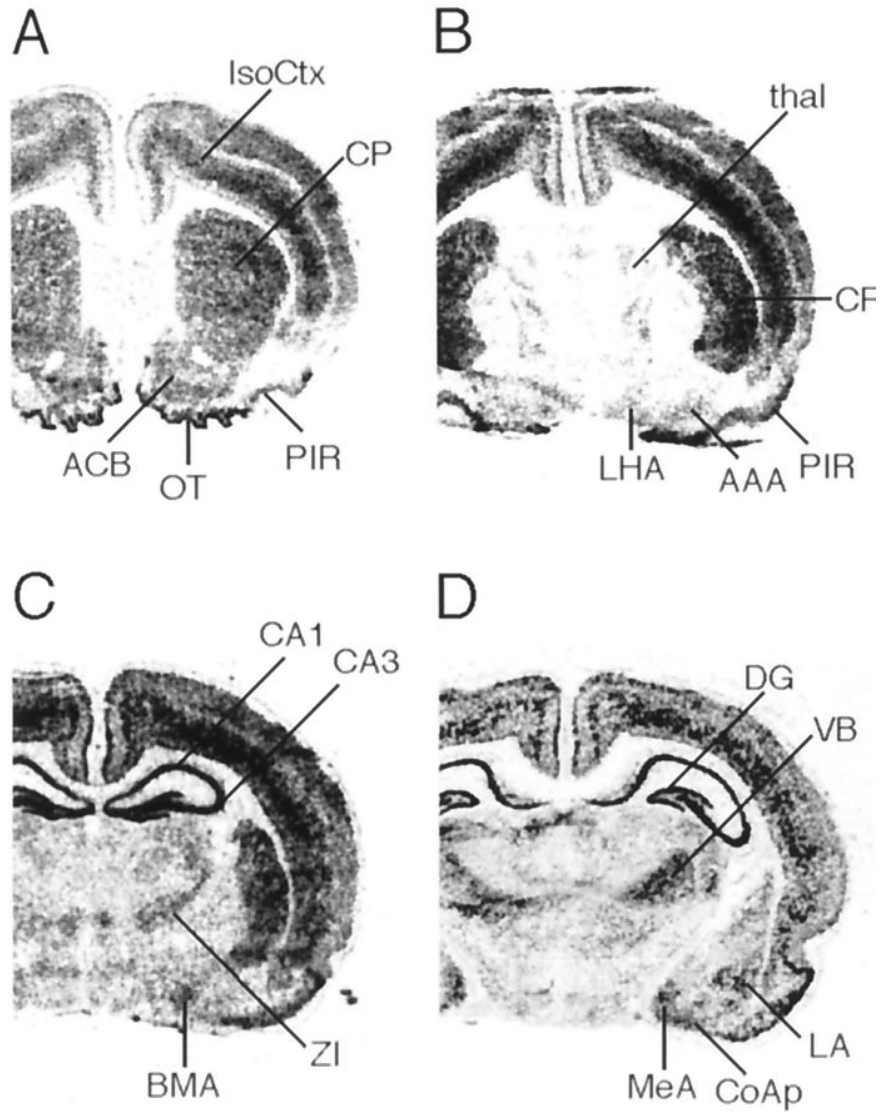

Figure 7. Expression of Srg1 in neonatal rat brain. Shown is in situ hybridization of coronal sections from $\mathrm{P} 14$ rat brain. Sections are shown rostral $(A)$ to caudal $(D)$. Hybridization with an antisense ${ }^{35} \mathrm{~S}$-cRNA probe from $\operatorname{Srg} 1$ is shown; sense probe gave no detectable signal. Shown are photomicrographs of an autoradiographic image of the hybridized section exposed directly to x-ray film. $A A A$, Anterior amygdaloid area; $A C B$, nucleus accumbens; $B M A$, basal medial amygdala; $C A 1, C A 3$, regions of hippocampus; $C o A p$, cortical nucleus amygdala, posterior part; $C P$, caudate putamen; $D G$, dentate gyrus; IsoCtx, isocortex; $L A$, lateral nucleus; $L H A$, lateral hypothalamic area; $M e A$, medial nucleus amygdala; $O T$, olfactory tubercle; $P I R$, piriform area; thal, thalamus; $V B$, ventrobasal complex, thalamus; $Z I$, zona incerta.

1972a-c; Rakic, 1972; Hatten and Heintz, 1995). Both genes appear to be expressed in terminally differentiated cerebellar neurons and not in neuronal precursors. Thyroid hormone has been implicated in promoting neuronal differentiation in the cerebellum (Nicholson and Altman, 1972b) and has been shown to be involved in differentiation of oligodendrocytes (Barres et al., 1994). Based on these observations, an attractive hypothesis is that the function of $h r$ is in establishment or maintenance of a differentiated state. The postulated function of Srg1 as a component of synapses (see below) makes it unlikely that Srg1 is involved directly in differentiation.

\section{Srg1, a novel gene related to synaptotagmin}

One of the genes isolated in this screen ( $\operatorname{Srg} 1)$ encodes a novel protein related to synaptotagmin(s). Synaptotagmins comprise a family of $\mathrm{Ca}^{2+}$ /phospholipid-binding proteins found in the brain (Perin et al., 1990; Geppert et al., 1991; Hilbush and Morgan, 1994; Mizuta et al., 1994; Li et al., 1995). Among the eight related genes that have been identified (syt I-VIII), four also are expressed outside the nervous system (Mizuta et al., 1994; Li et al., 1995). The functional significance of multiple synaptotagmins is 
not clear. Mice lacking a functional syt I gene are deficient in the fast component of $\mathrm{Ca}^{2+}$-mediated neurotransmitter release at hippocampal synapses (Geppert et al., 1994). Syt III is expressed in the same hippocampal neurons as syt I but does not substitute for syt I, suggesting that synaptotagmins do not have redundant functions (Ullrich et al., 1994).

Srg1 and synaptotagmins share a common structure that includes a C-terminal region consisting of two domains related to the regulatory region of protein kinase $\mathrm{C}$ ( $\mathrm{C} 2$ domains). The $\mathrm{N}$-terminal C2 domain (C2-A) of multiple synaptotagmins has been shown to bind $\mathrm{Ca}^{2+}$ and phospholipids (Davletov and Sudhof, 1993; Li et al., 1995). The C-terminal C2 domain (C2-B) has been shown to bind a clathrin-coated vesicle protein complex (AP-2) and syntaxins (Zhang et al., 1994; Li et al., 1995); all known synaptotagmins bind AP-2 and syntaxin. $\operatorname{Srg} 1$ is related to synaptotagmins more in the C2-B domain (33-42\% amino acid identity) than in the C2-A domain (19-31\%) and is most related to syt IV and syt VI, forms that do not bind $\mathrm{Ca}^{2+}$ and phospholipids. Based on structural similarity, Srg1 is likely to bind AP-2 and syntaxins but may not bind $\mathrm{Ca}^{2+}$ and phospholipids. Further studies will determine whether $\operatorname{Srg} 1$ can be classified functionally with synaptotagmins.

Regulation by thyroid hormone suggests that $\operatorname{Srg} 1$ may have unique functions among the synaptotagmins; other synaptotagmins have been tested (syt I and syt III) and are not induced by thyroid hormone. The brains of thyroid hormone-deficient animals are estimated to have approximately one-half the number of synapses of euthyroid animals (Eayrs, 1968; Nicholson and Altman, 1972a). Overall reduction in the number of interneuronal connections has been proposed to be the cause of behavioral changes in experimental animals and mental retardation in humans (Eayrs, 1968; Schwartz, 1983). Therefore, it is tempting to speculate that $\operatorname{Srg} 1$ may have a role in synaptogenesis or synaptic remodeling, processes in which synaptotagmins previously were not implicated. The temporal and spatial pattern of expression of Srg1 in the cerebellum is consistent with this hypothesis. Srg1 is expressed in the cerebellar IGL; migration of cells from the EGL to the IGL immediately precedes synapse formation by these cells.

\section{$h r$, the rat homolog of hairless}

This screen also identified a gene, hairless, not previously known to be TH-responsive. $h r$ is regulated by thyroid hormone in brain, yet its expression is not influenced by thyroid hormone in skin. This unusual tissue-specific regulation may indicate a functional difference in the action of $h r$ in brain and skin.

The murine hairless locus was identified as a spontaneous mutation caused by the insertion of an endogenous retrovirus between exons 6 and 7 (Stoye et al., 1988; Cachon-Gonzalez et al., 1994). The most prominent phenotype of homozygous mutant ( $h r / h r)$ mice is that $\sim 2$ weeks after birth they experience progressive hair loss. After their coat is shed completely (3-4 weeks of age), they remain bald. These animals show increased sensitivity to UV and chemically induced skin cancer (Poland et al., 1982; de Gruijl and Forbes, 1995). In both skin and brain, homozygous mutant hairless mice have $\sim 20$-fold less $h r$ mRNA than heterozygotes (my unpublished observations). Although reduction of $h r$ mRNA and, presumably, protein results in an obvious skin phenotype, the phenotype in the brain has not been determined. Generation of hairless null mutant mice will provide a useful tool for determining the in vivo function of $h r$ in the nervous system; future studies will also examine whether mice homozygous for existing $h r$ alleles have brain defects resembling those of hypothyroid animals.

The protein encoded by $h r$ has a putative zinc finger domain. Although the zinc finger motif usually occurs in multiple copies, several large proteins in a variety of species contain a single zinc finger (Friden and Schimmel, 1987; Evans and Hollenberg, 1988; Fu and Marzluf, 1990; Kudla et al., 1990; Tang et al., 1994), many of which have been implicated in transcriptional regulation. $h r$ has a cluster of six cysteines with novel spacing that is conserved among mouse, rat, and human (Cachon-Gonzalez et al., 1994; my unpublished observations). In addition, $h r$ is related to a gene with testes-specific expression identified in rat (TSGA; Höög et al., 1991). The proteins encoded by $h r$ and TSGA show $33 \%$ amino acid identity over a 260 amino acid region at their respective $\mathrm{C}$ termini. The putative zinc finger domain lies outside this 260 amino acid region, yet the arrangement of six cysteine residues is conserved (shown below; underlined residues are conserved between $h r$ and TSGA).

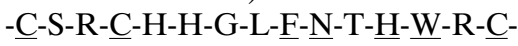

S-H-C- $-\underline{S}-H-R-L-\underline{C}-\underline{V}-\mathrm{A}-\underline{C}-\mathrm{G}-\underline{R}-\mathrm{I}-$

This configuration may be functionally significant; $\mathrm{hr}$ and TSGA may be representative of a new class of zinc finger proteins. Given the functional roles of other zinc finger proteins, the zinc finger domain of $h r$ is likely to have a role in nucleic acid binding and/or protein-protein interactions.

\section{Conclusions}

Thyroid hormone affects neural development by initiating a finely tuned program of gene expression. The results presented here suggest that this thyroid hormone-induced genetic program includes $\operatorname{Srg} 1$ and $h r$, making these genes excellent candidates for performing important functions in neural development. The success of this screen in identifying TH-responsive genes opens new avenues for studying the molecular effects of thyroid hormone on the mammalian CNS.

\section{REFERENCES}

Altman J (1972a) Postnatal development of the cerebellar cortex in the rat. I. The external germinal layer and the transitional molecular layer. J Comp Neurol 145:353-398.

Altman J (1972b) Postnatal development of the cerebellar cortex in the rat. II. The external germinal layer and the transitional molecular layer. J Comp Neurol 145:399-464.

Altman J (1972c) Postnatal development of the cerebellar cortex in the rat. III. The external germinal layer and the transitional molecular layer. J Comp Neurol 145:465-514.

Barres BA, Lazar MA, Raff MC (1994) A novel role for thyroid hormone, glucocorticoids, and retinoic acid in timing oligodendrocyte development. Development (Camb) 120:1097-1108.

Bennett MK, Scheller RH (1994) A molecular description of synaptic vesicle membrane trafficking. Annu Rev Biochem 63:63-100.

Bradley DJ, Towle HC, Young WS (1992) Spatial and temporal expression of $\alpha$ and $\beta$ thyroid hormone receptor mRNAs, including the $\beta 2$ subtype, in the developing mammalian nervous system. J Neurosci 12:2288-2302.

Cachon-Gonzalez MB, Fenner S, Coffin JM, Moran C, Best S, Stoye JP (1994) Structure and expression of the hairless gene of mice. Proc Natl Acad Sci USA 91:7717-7721.

Chomczynski P, Sacchi N (1987) Single-step method of RNA isolation by acid guanidinium thiocyanate-phenol-chloroform extraction. Anal Biochem 162:156-159.

Davletov BA, Sudhof TC (1993) A single C2-domain from synaptotagmin I is sufficient for high affinity $\mathrm{Ca}^{2+} /$ phospholipid-binding. J Biol Chem 268:26386-26390.

de Gruijl R, Forbes PD (1995) UV-induced skin cancer in a hairless mouse model. BioEssays 17:651-660. 
DeLong GR, Adams RD (1991) The neuromuscular system and brain in hypothyroidism. In: The thyroid (Braverman LE, Utiger RD, eds), pp 1027-1039. New York: Lippincott.

Eayrs JT (1968) Endocrinology and human behavior (Michael RP, ed), pp 331-363. London: Oxford UP.

Evans RM, Hollenberg SM (1988) Zinc fingers: gilt by association. Cell 52:1-3.

Farsetti A, Mitsuhashi T, Desvergne B, Robbins J, Nikodem VM (1991) Molecular basis of thyroid hormone regulation of myelin basic protein gene expression in rodent brain. J Biol Chem 266:23266-23232.

Feinberg AP, Vogelstein B (1984) A technique for radiolabeling DNA restriction endonuclease fragments to high specific activity. Anal Biochem 132:6-13.

Forrest D, Hallböök F, Persson H, Vennströmm B (1991) Distinct functions for thyroid hormone receptors $\alpha$ and $\beta$ in brain development indicated by differential expression of receptor genes. EMBO J 10:269-275.

Friden P, Schimmel P (1987) LEU3 of Saccharomyces cerevisiae encodes a factor for control of RNA levels of a group of leucine-specific genes. Mol Cell Biol 7:2708-2717.

Frohman MA, Dush MK, Martin GR (1988) Rapid production of fulllength cDNAs from rare transcripts: amplification using a single genespecific oligonucleotide primer. Proc Natl Acad Sci USA 85:8998-9002.

Fu Y-H, Marzluf GA (1990) Nit-2, the major nitrogen regulatory gene of Neurospora crassa, encodes a protein with a putative zinc finger DNAbinding domain. Mol Cell Biol 10:1056-1065.

Geppert M, Archer III BT, Sudhof TC (1991) Synaptotagmin II: a novel differentially distributed form of synaptotagmin. J Biol Chem 266:13548-13552.

Geppert M, Goda Y, Hammer RE, Li C, Rosahl TW, Stevens CF, Sudhof TC (1994) Synaptotagmin I: a major $\mathrm{Ca}^{2+}$ sensor for transmitter release at central synapses. Cell 79:717-727.

Hatten ME, Heintz N (1995) Mechanisms of neural patterning and specification in the developing cerebellum. Annu Rev Neurosci 18:385-408.

Hilbush BS, Morgan JI (1994) A third synaptotagmin gene, Syt3, in the mouse. Proc Natl Acad Sci USA 91:8195-8199.

Höög C, Schalling M, Grunder-Brundell E, Daneholt B (1991) Analysis of a murine male germ cell-specific transcript that encodes a putative zinc finger protein. Mol Reprod Dev 30:173-181.

Kanamori A, Brown DD (1992) The regulation of thyroid hormone receptor $\beta$ genes by thyroid hormone in Xenopus laevis. J Biol Chem 267:739-745.

Kudla B, Caddick MX, Langdon T, Martinez-Rossi NM, Bennett CF, Sibley S, Davies RW, Arst Jr HN (1990) The regulatory gene areA mediating nitrogen metabolite repression in Aspergillus nidulans. Mutations affecting specificity of gene activation alter a loop residue of a putative zinc finger. EMBO J 9:1355-1364.

Legrand J (1979) Morphogenetic actions of thyroid hormones. Trends Neurosci 2:234-236.

Li C, Ullrich B, Zhang JZ, Anderson RGW, Brose N, Sudhof TC (1995) $\mathrm{Ca}^{2+}$-dependent and independent activities of neural and non-neural synaptotagmins. Nature 375:594-599.

Loh EY, Elliot JF, Cwirla S, Lanier LL, Davis MM (1989) Polymerase chain reaction with single-sided specificity: analysis of T cell receptor $\delta$ chain. Science 243:217-220.

Mangelsdorf DJ, Thummel C, Beato M, Herrlich P, Schutz G, Umesono K, Blumberg B, Kastner P, Mark M, Chambon P, Evans RM (1995) The nuclear receptor superfamily: the second decade. Cell 83:835-839.

Mellström B, Naranjo JR, Santos A, Gonzalez AM, Bernal J (1991) Independent expression of the $\alpha$ and $\beta$ c-erbA genes in developing rat brain. Mol Endocrinol 5:1339-1350.

Mizuta M, Inagaki N, Nemoto Y, Matsukura S, Takahashi M, Seino S (1994) Synaptotagmin III is a novel isoform of rat synaptotagmin expressed in endocrine and neuronal cells. J Biol Chem 269:11675-11678.

Morreale de Escobar G, Ruiz-Marcos A, Escobar del Rey F (1983) Thyroid hormone and the developing brain. In: Congenital hypothyroidism (Dussault JH, Walker P, eds), pp 85-126. New York: Dekker.

Munoz A, Rodriguez-Pena A, Perez-Castillo A, Ferreiro B, Sutcliffe JG, Bernal J (1991) Effects of neonatal hypothyroidism on rat brain gene expression. Mol Endocrinol 5:273-280.
Murray MB, Zilz ND, McCreary NL, MacDonald MJ, Towle HC (1988) Isolation and characterization of rat cDNA clones for two distinct thyroid hormone receptors. J Biol Chem 263:12770-12777.

Nicholson JL, Altman J (1972a) Synaptogenesis in the rat cerebellum: effects of early hypo- and hyperthyroidism. Science 176:530-532.

Nicholson JL, Altman J (1972b) The effects of early hypo- and hyperthyroidism on the development of the rat cerebellar cortex (I and II). Brain Res 44:13-36.

Oppenheimer JH (1991) Thyroid hormone action at the molecular level. In: The thyroid (Braverman LE, Utiger RD, eds), pp 204-224. New York: Lippincott.

Perin MS, Fried VA, Mignery GA, Jahn R, Sudhof TC (1990) Phospholipid binding by a synaptic vesicle protein homologous to the regulatory region of protein kinase C. Nature 345:260-261.

Pipaon C, Santos A, Perez-Castillo A (1992) Thyroid hormone upregulates NGFI-A gene expression in rat brain during development. J Biol Chem 267:21-23.

Poland A, Palen D, Glover E (1982) Tumour production by TCDD in skin of HRS/J mice. Nature 300:271-273.

Rakic P (1972) Extrinsic cytological determinants of basket and stellate cell dendritic pattern in the cerebellar molecular layer. J Comp Neurol 146:335-354.

Sambrook J, Fritsch EF, Maniatis T (1989) Molecular cloning: a laboratory manual, pp. 7.26-7.29. Cold Spring Harbor, NY: Cold Spring Harbor Laboratory.

Samuels HH, Stanley F, Casanova J (1979) Depletion of L-3,5,3' triiodothyronine and L-thyroxine in euthyroid calf serum for use in cell culture studies of the action of thyroid hormone. Endocrinology 105:80-85.

Schwartz HL (1983) Effect of thyroid hormone on growth and development. In: Molecular basis of thyroid hormone action (Oppenheimer JH, Samuels HH, eds), pp 413-444. New York: Academic.

Simerly RB, Young BJ (1991) Regulation of estrogen receptor mRNA in rat hypothalamus by sex steroid hormones. Mol Endocrinol 5:424-432.

Simmons DM, Arriza JL, Swanson LW (1989) A complete protocol for in situ hybridization of messenger RNAs in brain and other tissues with radiolabeled single-stranded RNA probes. J Histotechnol 12:169-181.

Stoye JP, Fenner S, Greenoak GE, Moran C, Coffin JM (1988) Role of endogenous retroviruses as mutagens: the hairless mutation of mice. Cell 54:383-391.

Strait KA, Schwartz HL, Perez-Castillo A, Oppenheimer JH (1990) Relationship of c-erbA mRNA content to tissue triiodothyronine nuclear binding capacity and function in developing and adult rats. J Biol Chem 265:10514-10521.

Strait KA, Zou L, Oppenheimer JH (1992) $\beta 1$ isoform-specific regulation of a triiodothyronine-induced gene during cerebellar development. Mol Endocrinol 6:1874-1880.

Sudhof TC (1995) The synaptic vesicle cycle: a cascade of protein-protein interactions. Nature 375:645-653.

Tang CSL, Buenos A, Russell P (1994) Ntf1 ${ }^{+}$encodes a 6-cysteine zinc finger-containing transcription factor that regulates the $n m t 1$ promoter in fission yeast. J Biol Chem 269:11921-11926.

Thompson CC, Weinberger CW, Lebo R, Evans RM (1987) Identification of a novel thyroid hormone receptor expressed in the mammalian central nervous system. Science 237:1610-1614.

Tsai M-J, O’Malley BW (1994) Molecular mechanisms of action of steroid/thyroid receptor superfamily members. Annu Rev Biochem 63:451-486.

Ullrich B, Li C, Zhang JZ, McMahon H, Anderson RGW, Geppert M, Sudhof TC (1994) Functional properties of multiple synaptotagmins in brain. Neuron 13:1281-1291.

Wang Z, Brown DD (1991) A gene expression screen. Proc Natl Acad Sci USA 88:11505-11509.

Zhang JZ, Davletov BA, Sudhof TC, Anderson RGW (1994) Synaptotagmin $\mathrm{I}$ is a high affinity receptor for clathrin AP-2: implications for membrane recycling. Cell 78:751-760. 